\title{
Al-Mo-Sc (Aluminum-Molybdenum-Scandium)
}

\section{Raghavan}

An isothermal section at $550{ }^{\circ} \mathrm{C}$ and a vertical section in the Al-rich region were reported by [1990Che] for this ternary system. Since then, the Al-Mo binary phase diagram has undergone considerable changes in the Al-rich region [2006Eum] and only a tentative isothermal section at $550{ }^{\circ} \mathrm{C}$ is given here.

\section{Binary Systems}

The Al-Mo phase diagram [2006Eum] depicts the following intermediate phases: $\mathrm{MoAl}_{12}\left(\mathrm{Al}_{12} \mathrm{~W}\right.$-type cubic), $\mathrm{MoAl}_{5}(\mathrm{r})$ (rhombohedral, space group $R \overline{3} \mathrm{c}$ ), $\mathrm{MoAl}_{5}\left(\mathrm{~h}^{\prime}\right)$ (hexagonal, P321), $\mathrm{MoAl}_{5}(\mathrm{~h})$ (hexagonal, $P 6_{3} 22$ ), $\mathrm{Mo}_{5} \mathrm{Al}_{22}$ (orthorhombic, Fdd2), $\mathrm{Mo}_{4} \mathrm{Al}_{17}$ (monoclinic, C2), $\mathrm{MoAl}_{4}$ (monoclinic, $C m$ ), $\mathrm{MoAl}_{3}$ (monoclinic, $C 2 / m$ ), $\mathrm{Mo}_{3} \mathrm{Al}_{8}$ (monoclinic, $C m$ ), $\mathrm{Al}_{63} \mathrm{Mo}_{37}, \mathrm{MoAl}$ (bcc), and $\mathrm{Mo}_{3} \mathrm{Al}(A 15$, $\mathrm{Cr}_{3}$ Si-type cubic). The Al-Sc phase diagram [Massalski2] depicts the following intermediate compounds: $\mathrm{ScAl}_{3}$ ( $L 1_{2}, \mathrm{AuCu}_{3}$-type cubic), $\mathrm{ScAl}_{2}\left(C 15, \mathrm{MgCu}_{2}\right.$-type cubic), $\mathrm{ScAl}$ (B2, CsCl-type cubic) and $\mathrm{Sc}_{2} \mathrm{Al}\left(B 8_{2}, \mathrm{Ni}_{2}\right.$ In-type hexagonal). There are no intermediate phases in the Mo-Sc system, which exhibits a eutectic solidification.

\section{Ternary Isothermal Section}

With starting metals of $99.999 \% \mathrm{Al}, 99.97 \% \mathrm{Mo}$, and pure Sc, [1990Che] prepared alloys by electron beam melting under Ar atm. The alloys were annealed at $550{ }^{\circ} \mathrm{C}$ for $720 \mathrm{~h}$ and quenched. The phase equilibria were studied by $\mathrm{x}$-ray powder diffraction, differential thermal analysis, and transmission electron microscopy. The isothermal section at $550{ }^{\circ} \mathrm{C}$ constructed by [1990Che] in the Al-rich region is redrawn tentatively in Fig. 1 to agree with the accepted binary data.

The vertical section constructed by [1990Che] is difficult to interpret due to the binary discrepancies and is not given here. The final solidification at the Al-end occurs through a

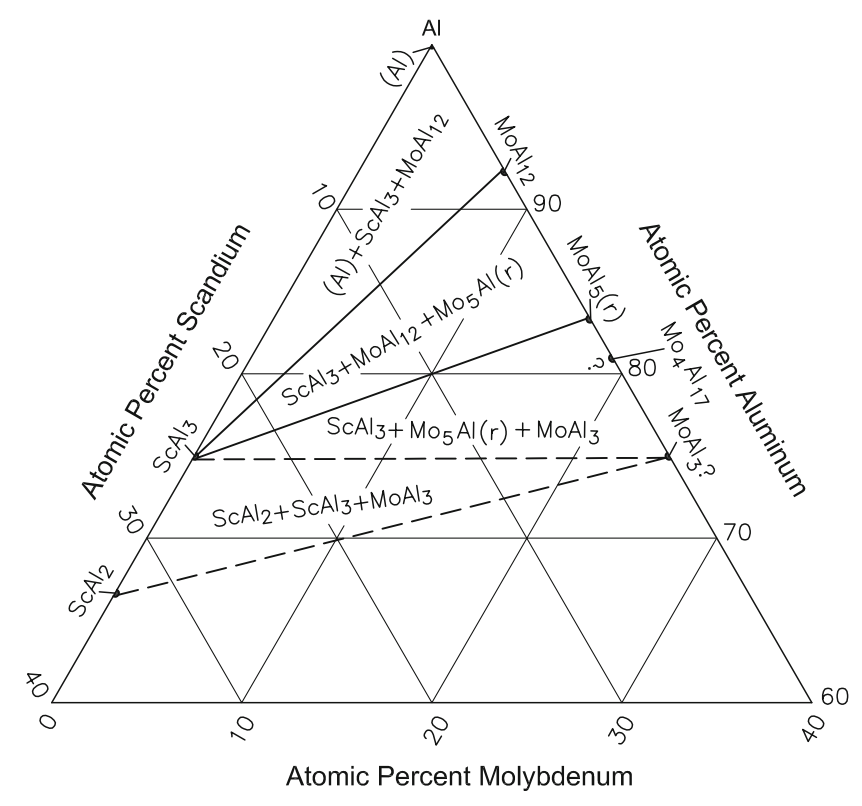

Fig. 1 Al-Mo-Sc tentative isothermal section at $550{ }^{\circ} \mathrm{C}$ for Al-rich alloys [1990Che]. Two-phase regions are omitted

ternary eutectic reaction: $L \leftrightarrow(\mathrm{Al})+\mathrm{ScAl}_{3}+\mathrm{MoAl}_{12}$, just below $600{ }^{\circ} \mathrm{C}$. [1990Che] also studied the formation of metastable phases by rapid quenching and their subsequent decomposition during ageing.

\section{References}

1990Che: G.M. Chel'dieva, E.F. Kazakova, E.M. Sokolovskaya, and N.I. Kaloev, Formation and Decomposition of Metastable Phases in Aluminum Alloys, Metally, 1990, (6), p 88-91, in Russian; TR: Russ. Metall., 1990, (6), p 87-90

2006Eum: M. Eumann, G. Sauthoff, and M. Palm, Re-evaluation of Phase Equilibria in the Al-Mo System, Int. J. Mater. Res., 2006, 97(11), p 1502-1511 